\title{
Digital Database of Channel Cross-Section Surveys, Mount St. Helens, Washington
}

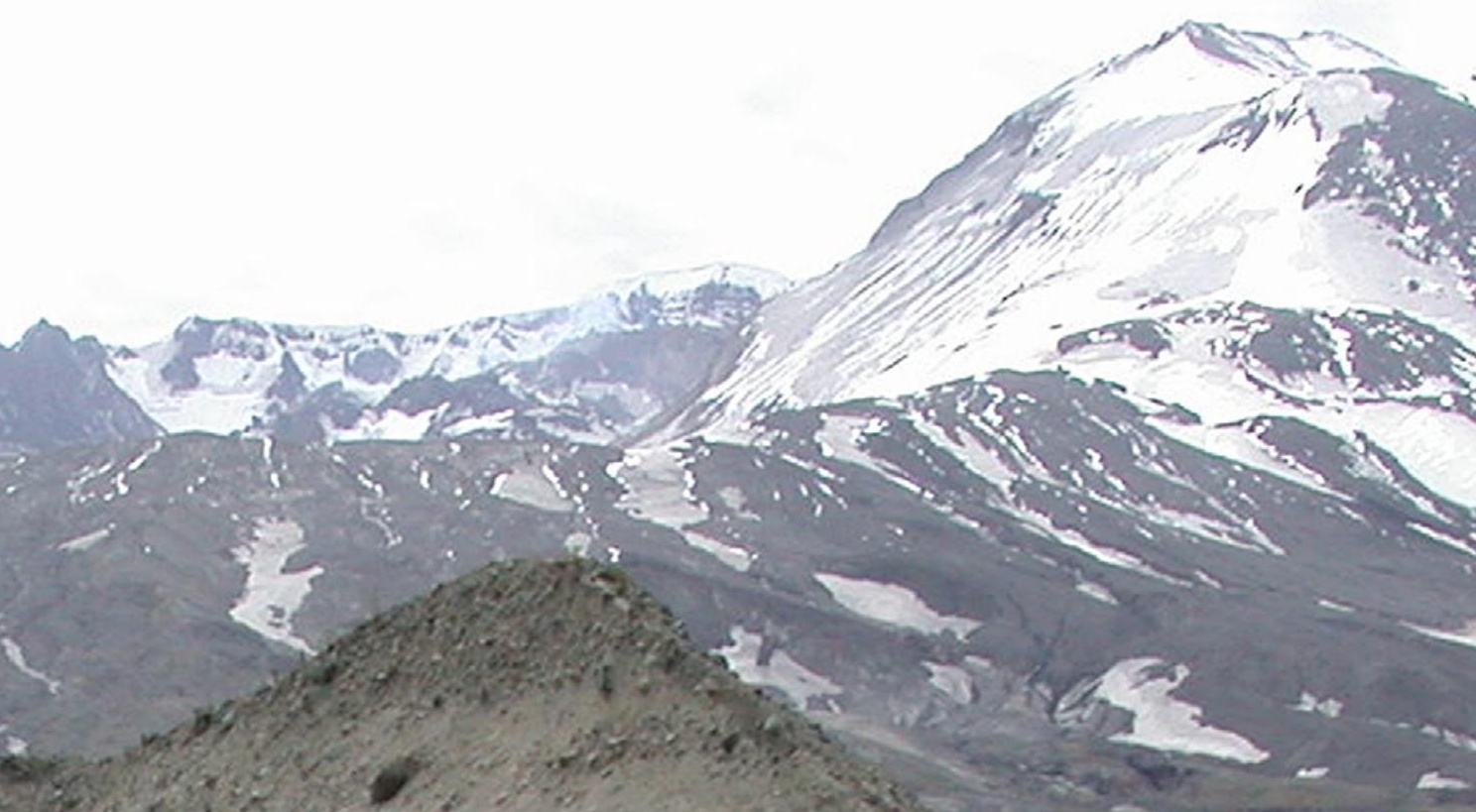


COVER. Photograph of Loowit Creek cross section L0033 taken on May 25, 2007. View is upstream with Mount St. Helens, Washington, in the background. (U.S. Geological Survey photograph.) 


\section{Digital Database of Channel Cross-Section Surveys, Mount St. Helens, Washington}

By Adam R. Mosbrucker, Kurt R. Spicer, Jon J. Major, Dennis R. Saunders, Tami

S. Christianson, and Cole G. Kingsbury

Data Series 951

Version 1.1, April 2018 


\title{
U.S. Department of the Interior \\ RYAN K. ZINKE, Secretary
}

\section{U.S. Geological Survey William H. Werkheiser, Deputy Director exercising the authority of the Director}

\author{
U.S. Geological Survey, Reston, Virginia \\ First release: 2015 \\ Revised: April 2018 (ver. 1.1)
}

For more information on the USGS - the Federal source for science about the Earth, its natural and living resources, natural hazards, and the environment—visit http://www.usgs.gov or call 1-888-ASK-USGS (1-888-275-8747).

For an overview of USGS information products, including maps, imagery, and publications, visit http://www.usgs.gov/pubprod/.

Any use of trade, firm, or product names is for descriptive purposes only and does not imply endorsement by the U.S. Government.

Although this information product, for the most part, is in the public domain, it also may contain copyrighted materials as noted in the text. Permission to reproduce copyrighted items must be secured from the copyright owner.

Suggested citation:

Mosbrucker, A.R., Spicer, K.R., Major, J.J., Saunders, D.R., Christianson, T.S., and Kingsbury, C.G., 2015, Digital database of channel cross-section surveys, Mount St. Helens, Washington (ver. 1.1, April 2018): U.S. Geological Survey Data Series 951, 9 p. and supplemental data, https://doi.org/10.3133/ds951.

ISSN 2327-638X (online) 


\section{Contents}

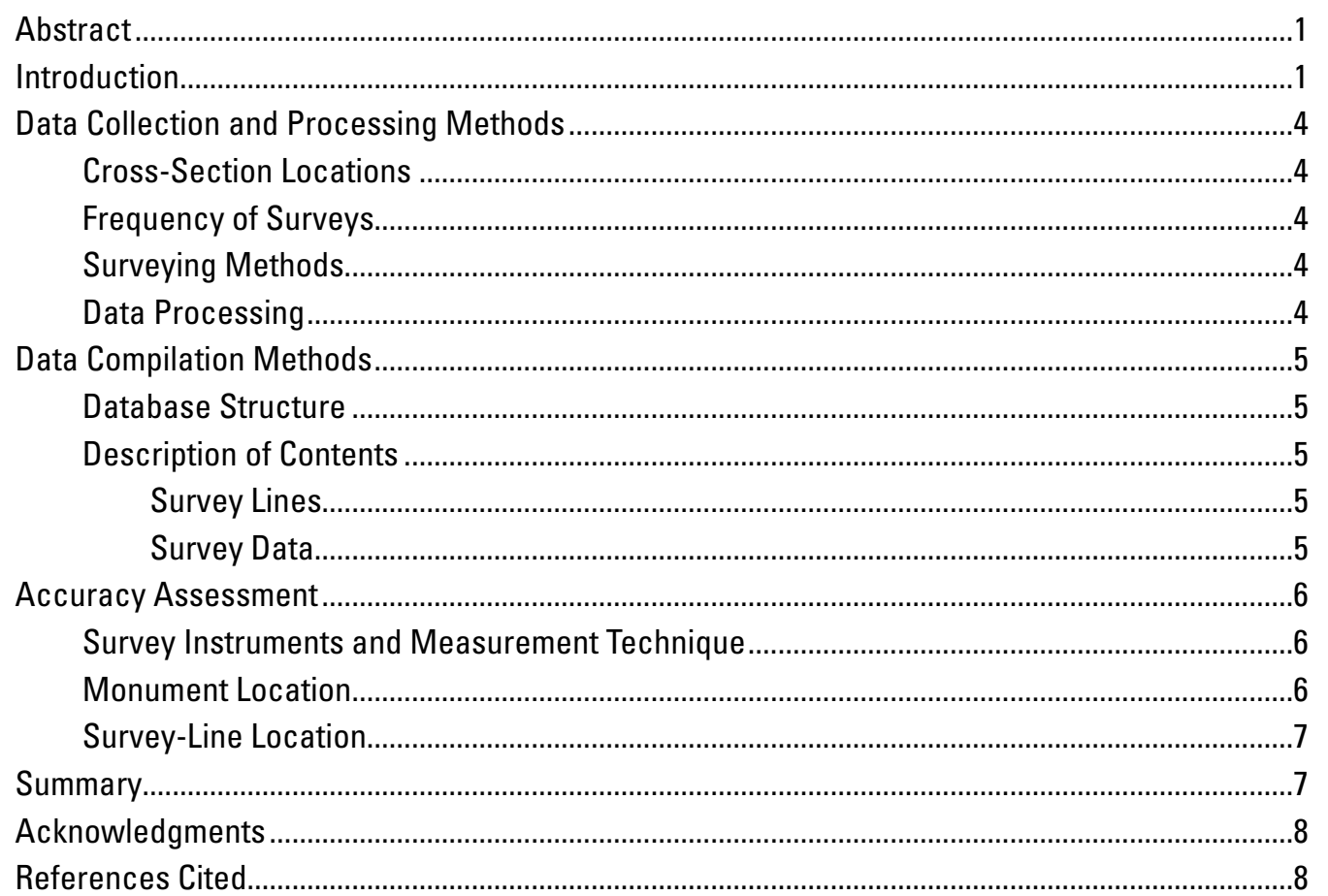




\section{Figures}

1. Map showing drainage-basin names, hydrographic features, cross-section locations, and U.S. Geological Survey surface-water and sediment discharge gages at Mount St. Helens, Washington........................................................................................2

2. Map showing drainage-basin names and volcanic processes of the May 18, 1980, eruption of Mount St. Helens, Washington...

\section{Tables}

1. Monument geographic location source and quality summary statistics at the time of publication for this Mount St. Helens, Washington, database

2. Selection of 46 unrectified survey lines before and after rectification, comparing line length in meters, for this Mount St. Helens, Washington, database

3. Selection of 90 unrectified survey lines before and after rectification, comparing distance between polyline nodes in meters, for this Mount St. Helens, Washington, database. 


\section{Conversion Factors}

[International System of Units to Inch/Pound]

\begin{tabular}{lll}
\hline \multicolumn{1}{c}{ Multiply } & \multicolumn{1}{c}{ By } & \multicolumn{1}{c}{ To obtain } \\
\hline centimeter $(\mathrm{cm})$ & centimeter $(\mathrm{cm})$ & inch (in.) \\
cubic kilometer $\left(\mathrm{km}^{3}\right)$ & cubic kilometer $\left(\mathrm{km}^{3}\right)$ & cubic mile $\left(\mathrm{mi}^{3}\right)$ \\
kilometer $(\mathrm{km})$ & kilometer $(\mathrm{km})$ & mile $(\mathrm{mi})$ \\
meter $(\mathrm{m})$ & meter $(\mathrm{m})$ & foot $(\mathrm{ft})$ \\
meter $(\mathrm{m})$ & meter $(\mathrm{m})$ & yard $(\mathrm{yd})$ \\
millimeter $(\mathrm{mm})$ & millimeter $(\mathrm{mm})$ & inch (in.) \\
square kilometer $\left(\mathrm{km}^{2}\right)$ & square kilometer $\left(\mathrm{km}^{2}\right)$ & acre \\
square kilometer $\left(\mathrm{km}^{2}\right)$ & square kilometer $\left(\mathrm{km}^{2}\right)$ & square mile $\left(\mathrm{mi}^{2}\right)$ \\
\hline
\end{tabular}

\section{Supplemental Information}

Vertical coordinate information is referenced to the North American Vertical Datum of 1988 (NAVD88).

Horizontal coordinate information is referenced to the North American Datum of 1983 (NAD83).

Elevation, as used in this report, refers to distance above the vertical datum.

Water year (WY) is the 12-month period from 0ctober 1 through September 30 and is identified by the calendar year in which it ends. For example, the period October 1, 2014, through September 2015, is designated water year 2015. 



\title{
Digital Database of Channel Cross-Section Surveys, Mount St. Helens, Washington
}

\author{
By Adam R. Mosbrucker, ${ }^{1}$ Kurt R. Spicer, ${ }^{1}$ Jon J. Major, ${ }^{1}$ Dennis R. Saunders, ${ }^{1}$ Tami S. Christianson, ${ }^{1}$ and \\ Cole G. Kingsbury²
}

\section{Abstract}

Stream-channel cross-section survey data are a fundamental component to studies of fluvial geomorphology. Such data provide important parameters required by many open-channel flow models, sediment-transport equations, sediment-budget computations, and flood-hazard assessments. At Mount St. Helens, Washington, the long-term response of channels to the May 18, 1980, eruption, which dramatically altered the hydrogeomorphic regime of several drainages, is documented by an exceptional time series of repeat stream-channel cross-section surveys. More than 300 cross sections, most established shortly following the eruption, represent more than 100 kilometers of surveyed topography. Although selected cross sections have been published previously in print form, we present a comprehensive digital database that includes geospatial and tabular data. Furthermore, survey data are referenced to a common geographic projection and to common datums. Database design, maintenance, and data dissemination are accomplished through a geographic information system (GIS) platform, which integrates survey data acquired with theodolite, total station, and global navigation satellite system (GNSS) instrumentation. Users can interactively perform advanced queries and geospatial time-series analysis. An accuracy assessment provides users the ability to quantify uncertainty within these data. At the time of publication, this project is ongoing. Regular database updates are expected; users are advised to confirm they are using the latest version.

\section{Introduction}

The May 18, 1980, eruption of Mount St. Helens, Washington, consisted of a 2.5 cubic kilometer $\left(\mathrm{km}^{3}\right)$ debris avalanche followed by a blast density current (called the lateral blast, that devastated about 600 square kilometers $\left(\mathrm{km}^{2}\right)$ of forested terrain), pyroclastic flows, lahars, and tephra falls (for example, Lipman and Mullineaux, 1981). These disturbances dramatically altered the hydrogeomorphic regime of several drainage basins (for example, Janda and others, 1984; Simon, 1999; Major and others, 2000; Major and Mark, 2006).

${ }^{1}$ U.S. Geological Survey.

${ }^{2}$ Carleton University, Department of Earth Sciences, Ottawa, Canada.
The long-term response of these channels to the eruption is characterized by an extensive time series of repeat stream channel cross-section surveys. The survey network is part of a long-term hydrologic monitoring project managed by the U.S. Geological Survey (USGS).

Cross sections are located within two primary drainage basins - the Toutle River on the north and west flanks of the volcano and the Lewis River on the south and east flanks. The Toutle River drains an area of $1,330 \mathrm{~km}^{2}$, originating as two separate forks - North Fork Toutle and South Fork Toutle Rivers - that flow in parallel basins trending west-northwest from the edifice of Mount St. Helens to the mainstem Toutle River, a tributary to the lower Cowlitz and Columbia Rivers. The North Fork Toutle River incorporates discharge from Spirit, Coldwater, and Castle Lakes, as well as the Green River, which flows west from rugged terrain north of Spirit Lake (fig. 1). The Lewis River flows 150 kilometers $(\mathrm{km})$ from the west flank of Mount Adams (50 km east of Mount St. Helens), westward through three reservoirs to the Columbia River. Drainage basins on the south (Swift and Pine Creeks) and east (Muddy River) sides of Mount St. Helens contribute $240 \mathrm{~km}^{2}$ of drainage (10 percent of the drainage area) to the Lewis River.

The eruption impacted drainage basins differently, causing subsequent hydrogeomorphic responses to vary with respect to process, magnitude, and duration. Cross sections were established to monitor channel response to a wide spectrum of volcanic impacts (Martinson and others, 1984; Meyer and others, 1986) (fig. 2). Although some drainages, such as the Green River and Clearwater Creek, experienced a transient response to disturbed hillslopes (Major and others, 2000), more severely disturbed basins, such as the Toutle and Muddy Rivers, continue to exhibit persistent channel adjustment and sediment transport rates greater than pre-eruption levels. The North Fork Toutle River basin experienced the greatest disturbance; severely modified by debris avalanche, lateral blast, pyroclastic flows, tephra falls, and subsequent debris flows, the hydrogeomorphic response continues to evolve. For this reason, a significant proportion of project resources are devoted to monitoring the North Fork Toutle River basin. More detailed discussions of eruption sequence, volcanic impacts, and hydrogeomorphic responses are presented in Lipman and Mullineaux (1981), Martinson and others (1984), Pierson (1985), Martinson and others (1986), Meyer and others (1986), Meyer and Dodge (1988), Meyer and Martinson (1989), Lisle (1995), Simon (1999), Major (2004), Swanson and Major (2005), Major and Mark (2006), Pierson and Major (2014), and Major and others (in press). 

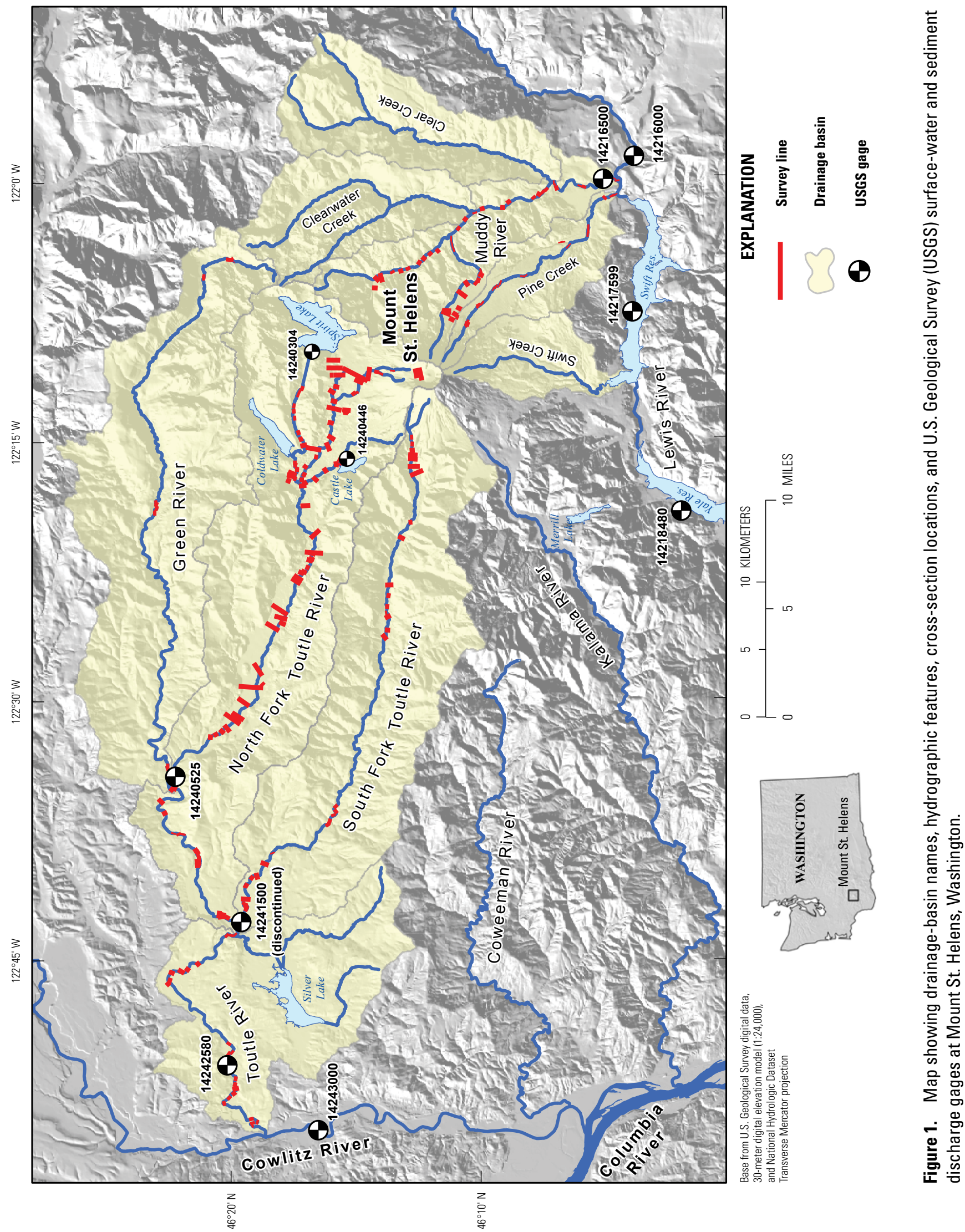

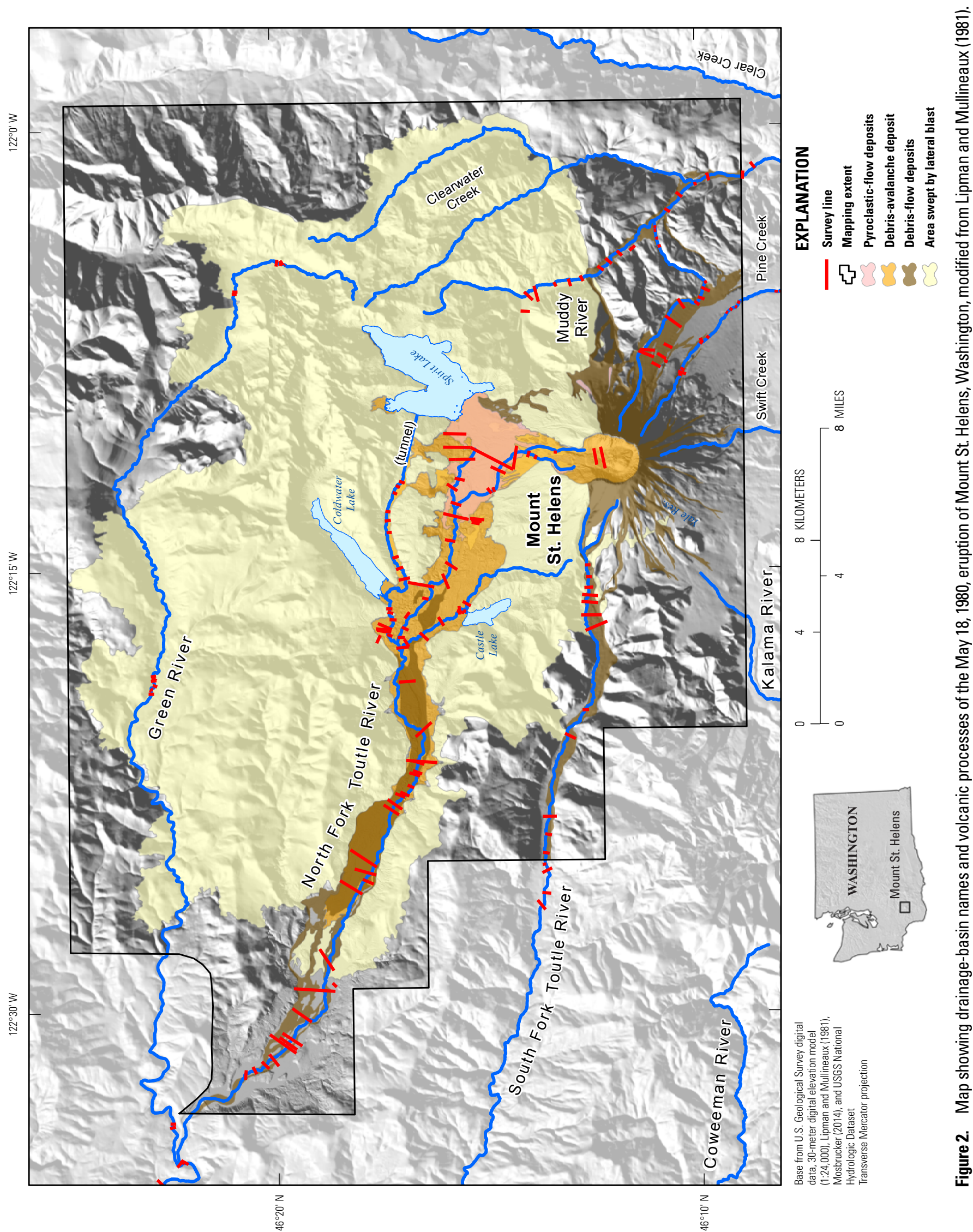
Early cross-section data have been summarized previously for the Toutle River drainage basin for water years ${ }^{3}$ (WY)1980-85 (Meyer and others, 1986; Meyer and Dodge, 1988) and for Lewis River tributaries for WY 1980-84 (Martinson and others, 1984; Martinson and others, 1986). Selected cross-section survey plots, stream-channel adjustments, sediment discharge, and related hazard-mitigating engineering works are summarized in Meyer and Martinson (1989), Lisle (1995), Simon (1999), Hardison (2000), West Consultants (2002), Biedenharn (2010), Simon and Klimetz (2012), Meadows (2014), Zheng and others (2014), and Major and others (in press). The comprehensive digital database presented here includes all available cross-section surveys, as well as geospatial and tabular data. At the time of initial publication, this database represents cross-section survey data acquired during WY1980-2013.

In this database we present more than 30 years of repeat stream channel cross-section survey data for Mount St. Helens study basins. This project is ongoing and regular updates are expected to be made. The current network consists of more than 300 monumented cross sections. We provide a summary of data collection and geographic information system (GIS) database compilation methods. We then quantify errors associated with these data through an accuracy assessment of both relative (internal survey data) and absolute (external or geodetic location) uncertainty. Our results indicate that topographic point measurements have an overall relative accuracy of $\sim 5-20$ centimeters ( $\mathrm{cm}$ ), whereas absolute accuracy varies tremendously (centimeters to several hundred meters) depending on data source.

\section{Data Collection and Processing Methods}

\section{Cross-Section Locations}

Beginning in summer 1980, cross sections were strategically located above and below the confluences of major tributaries; near pre- and post-eruption stream gages, bridges; and to coincide with cross sections measured photogrammetrically. Cross sections were commonly established in clusters of two or more to define study reaches (Martinson and others, 1984; Martinson and others, 1986; Meyer and others, 1986; Meyer and Dodge, 1988).

The cross-section network continues to be modified and expanded. Monuments are lost to bank erosion, channel widening, channel avulsion, and channel-bed aggradation. Some monuments have also been vandalized. Lost cross-section monuments are reestablished as close to the original location as possible, although some relocation has questionable control (Martinson and others, 1984; Martinson and others, 1986; Meyer and others, 1986; Meyer and Dodge, 1988). New cross sections are added to the network to capture recent trends in channel adjustment and to expand areal coverage.

\footnotetext{
${ }^{3} \mathrm{~A}$ water year runs from October 1 through September 30. For example, water year 1982 ran from October 1, 1981, through September 30, 1982.
}

\section{Frequency of Surveys}

Cross sections have not been surveyed on a regular time interval. From 1980 to 1984, more than 100 cross-section surveys were conducted each year. Following a peak of 215 surveys in 1984 , the number of cross sections surveyed each year declined to less than 50 by 1987 and to less than 23 by 1993, when channel adjustments in some basins had largely ceased. Since 1993, about 10 cross sections are surveyed annually. Surveys presently are prioritized by geomorphic activity level, research interest, or historical record quality.

\section{Surveying Methods}

Cross sections were established by a line of sight, approximately perpendicular to the active channel or valley floor. Horizontal and vertical control is provided by endpoints, monumented with steel fencepost or reinforcing bar. Since the establishment of the cross-section network in 1980, three primary methods have been used to collect data. Before 1992, surveys were conducted using a theodolite and electronic distance meter (EDM). The theodolite provided horizontal and vertical angles and the EDM measured slope distance from the instrument to a glass prism mounted on a survey rod. Since 1992, surveys are conducted using a total station (combined theodolite and EDM), primarily with a rod and prism. Beginning in 2009, global navigation satellite system (GNSS) technology was integrated into surveying efforts, providing high-precision location information and single-person surveying techniques.

Secondary surveying methods allow measurements to be made where deep gullies, vertical banks, or channels too deep to wade have prohibited the use of more precise techniques. These include hand level and tape and depth sounding from a bridge or boat. In some cases, maximum channel depth or physically inaccessible but significant slope breaks are estimated (Martinson and others, 1984; Martinson and others, 1986; Meyer and others, 1986; Meyer and Dodge, 1988). Since 2012, reflectorless totalstation technology has been used to accurately measure features inaccessible to a person carrying a survey rod, such as tall vertical banks.

\section{Data Processing}

Survey data are processed using a variety of field and office postprocessing software packages. Angle and slope-distance measurements are transformed to real-world (geodetic) coordinates using trigonometric functions and GNSS solutions. Topographic measurements are projected into Universal Transverse Mercator Zone 10 North (UTM Z10N) in units of meters. Horizontal datum is adjusted to the North American Datum of 1983 (NAD83); elevation is referenced to the North American Vertical Datum of 1988 (NAVD88) to produce orthometric height. Most NAVD88 values are computed from GNSS solutions using a hybrid geoid model developed by the National Geodetic Survey (NGS). At the time of publication, these include GEOID03, GEOID09, and 
GEOID12A (National Geodetic Survey, 2011a, 2011b, 2012); new geoid models may be used when available

\section{Data Compilation Methods}

Geospatial and cross-section survey data are presented with an interactive user interface. Geospatial data include survey lines and attributes. Survey data consist of horizontal distance and elevation, provided in tables and sample plots. Database design seeks to balance efficient user queries with more complex geospatial analysis.

\section{Database Structure}

The database uses an object-oriented data model to aggregate geospatial and non-spatial information into a single digital map. Developed and maintained using Esri ArcGIS software, the database stores geographic, geometric, and associated attribute fields for each survey line or object within a feature class. Fieldbased feature hyperlinks are used to access local file folders containing Microsoft Excel Workbooks (1997-2003) and Joint Photographic Experts Group (JPEG) files. These data can be accessed through a preconfigured ArcReader document (.pmf) that allows users to interactively query content. Geospatial data are provided as shapefiles, rather than as proprietary Esri geodatabase structure, so that other GIS packages can be used. The database is designed to be dynamic, with information updated, added, and made available as appropriate.

\section{Description of Contents}

The database consists of three main components - crosssection survey lines, tabular survey data, and survey-data plots. To provide the greatest flexibility for geospatial analysis, all surveyed coordinates are converted to a planar horizontal datum (UTM Z10N, NAD83) and consistent vertical datum (NAVD88), both in meters. Cross-section survey lines are identified using an alphanumeric naming convention whereby a two-letter stream code is followed by a three- or four-digit number. Numbers generally increase in a downstream direction. For example, a cross section identified as NF120 is located on the North Fork Toutle River, upstream of NF130 and downstream of NF110. Generally, survey lines retain the same identification code as used in previously published reports.

\section{Survey Lines}

At the time of publication, the database contains 243 survey lines, representing $\sim 100 \mathrm{~km}$ of topography. An additional 91 cross sections are not included because of a lack of geographic location information. Most of those sections were surveyed only once or twice shortly after the eruption and were not subsequently reoccupied. If these are located, they will be included in future database versions.
Cross-section survey lines are created in a GIS environment using monument point locations. These points are provided by GNSS solutions or computed from total station data. A survey line is represented in the database by a singlesegment polyline with two endpoints. Based on reference monument availability and ancillary data, survey lines are symbolized using three ordinal classes - rectified, interpreted, and unrectified.

The highest quality survey lines, attributed as rectified, are defined by at least two monuments - one on each side of the stream channel. Usually, the nodes (or endpoints) of rectified polylines are spatially coincident with the two monuments that are farthest apart and have the highest spatial precision. In some cases, lines have been extended beyond the farthest monument location using survey data. Medium-quality survey lines, attributed as interpreted, are defined by at least one monument on one side of the stream channel. Similar to rectified polylines, one node location is spatially coincident with the monument farthest from the stream channel. Ancillary data are used to estimate the location of the opposite node. Low-quality survey lines, attributed as unrectified, are not defined by monument locations. Node locations for unrectified polylines are digitized from hardcopy maps.

Survey lines are stored in a single feature class. Feature attributes include cross section identification (Label field), location quality classification used for symbolization (Quality field), first year surveyed (First_Surv field), last year surveyed (Last_Surv field), and survey-line length as represented by the GIS (Shape_Length field). Two fields (Surv_XLS_Link and Surv_JPG_Link) are populated with hyperlink paths to folders containing tabular survey data and sample plots; the Included field indicates whether tabular survey data and sample plots are available for a particular cross section for the current database version. At the time of publication, the ArcReader document can assign only one hyperlink field to a feature class. To overcome this limitation, the document contains two Survey_Line layers in the table of contents.

\section{Survey Data}

On querying a survey line, users are given two choices to access time-series data - tabular Microsoft Excel (.xls) files or a folder of sample plots (.jpg files). Each Excel file contains all surveys for a given cross section, ordered by date. Topographic measurements are presented as horizontal distance in meters (dist_ $m$ field) from a left bank monument (as viewed looking downstream) and elevation in meters above NAVD88 (elev_ $m$ field). Data gaps and values in the distance column that appear out of sequence allow survey lines to be easily plotted; these represent monuments and areas not surveyed (that is, no topographic change was observed by survey crew). JPEG files contain sample plots of selected surveys superimposed onto a single line graph to show cross-section profile changes through time. Scale and (or) vertical exaggeration vary among plots. Survey data attributed as Pending $Q A / Q C$ are not included for cross sections identified as needing additional review or datum corrections. 
Digital Database of Channel Cross-Section Surveys, Mount St. Helens, Washington

\section{Accuracy Assessment}

Data uncertainty originates from four sources - survey equipment, operator technique, monument location, and survey line location. Survey equipment provides highly precise internal measurements of horizontal distance and elevation, but quality can be compromised by operator error. Although many such errors are found and corrected during processing (mostly by comparison to previous survey data), it is possible some errors remain. Geospatial data define the external orientation of survey lines in geographic coordinates. Relative accuracy of internal measurements presented in the survey data files is preserved by not converting data to geographic coordinates; the absolute accuracy of geospatial data is kept separate. It is important for data users to understand inherent errors in each of these areas.

\section{Survey Instruments and Measurement Technique}

Accuracy and precision of survey data are dependent on instrument characteristics and measurement techniques. Error associated with survey technique generally overwhelms instrument precision.

Survey logistics almost always prevent traditional closure error measurements. Without these, instrument specifications and comparison of previously surveyed monuments are relied on to provide quantitative precision estimates. Theodolite precision is about \pm 6 arc seconds (Martinson and others 1984; Martinson and others, 1986). EDM distance measurements are affected by atmospheric temperature, pressure, and haze. Because of these factors, surveys of wide channels are not as precise as narrow channels. Instrument specifications suggest horizontal and vertical precision is about \pm 50 millimeter $(\mathrm{mm})$ per $\mathrm{km}$ of line length (Martinson and others, 1984, 1986; Hardison, 2000). For surveys conducted using a total station (typically with a rod and prism), measurement precision based on instrument specifications is typically 1 to 3 arc seconds and $\pm 3 \mathrm{~mm}+2 \mathrm{~mm}$ per $\mathrm{km}$ of line length. For example, at the mean cross-section line length of $0.4 \mathrm{~km}$, these specifications equate to a peak-topeak error (that is, separation, or range, of component values) of less than $6 \mathrm{~mm}$ combined horizontal and vertical accuracy. At the maximum cross-section line length of $2.1 \mathrm{~km}$, peak-to-peak error increases to as much as $30 \mathrm{~mm}$. Real-time or post-processed kinematic (RTK or PPK) GNSS instrumentation provides estimates of precision for each topographic point solution using proprietary statistical algorithms. GNSS position solutions are affected by a variety of inherent error. Some of these include baseline length, clock drift, satellite orbital bias and geometry, ionospheric and tropospheric signal delays, and multi-path errors. Many of these errors are avoided or corrected through survey methods and signal-processing techniques. Whenever possible, quality-assurance checks are performed before and after each survey (Rydlund and Densmore, 2012). Final solutions are typically less than $8 \mathrm{~mm}$ horizontal and $15 \mathrm{~mm}$ vertical $\pm 1 \mathrm{~mm}$ per $\mathrm{km}$ of baseline distance from the base station. For example, at a baseline length of $2.1 \mathrm{~km}$, root-mean-square-error (RMSE) for RTK and PPK GNSS solutions typically have an internal precision less than $20 \mathrm{~mm}$.

Survey technique dominates the error budget of crosssection measurements. Accuracy is affected by rod leveling and placement and measurement of rod height and instrument height. Sometimes, rods cannot be leveled precisely due to inadequate visibility, saturated ground, wind, or lack of a calibrated spirit level. Survey-rod placement has little affect on individual topographic-point measurements but can have a significant impact on dimensional analysis performed on repeat crosssection line plots. Topographic points are not selected in an equal interval method, but rather by the discretion of the surveyor and the ability to physically access steep slopes. Bangen and others (2014) found that survey-crew variability can introduce a larger degree of uncertainty (on the order of $200 \mathrm{~mm}$ ) than suggested by instrument specifications in the reproduction of rough surfaces that have not changed (Martinson and others, 1984; Martinson and others, 1986; Meyer and others, 1986; Meyer and Dodge, 1988). Due to the discretionary nature of topographic point selection, caution must be taken when comparing change in crosssectional area over time if analyzed at an inappropriate scale.

\section{Monument Location}

In the database, survey lines are defined by monument location within a high-precision geodatabase environment. Absolute (geodetic) accuracy of these geographic coordinates is a function of source GNSS solution quality and necessary datum transformations. Solution quality is highly dependent on instrumentation, observation length, and technique. Locations are provided by three types of GNSS instruments and techniques - recreation, map, and survey grade. Most solutions are from static observations. Static observation time ranges from 15 minutes to greater than 4 hours for survey grade, several minutes to an hour for map grade, and 1 to 5 minutes for recreation grade. Survey-grade RTK or PPK observation time are typically $\sim 3$ minutes, usually collected in pairs. Total-station measurements are integrated with solutions from all three types. Although survey-grade solutions compare well with total station measurement quality, map- or recreation-grade GNSS solutions limit absolute accuracy (table 1).

Vertical datum for most cross sections is provided by GNSS solutions at monuments. Absolute accuracy of elevation values, reported to meters above NAVD88, is a function of GNSS solutions $(2-8 \mathrm{~cm})$, the conversion from ellipsoidal to orthometric heights $(1-5 \mathrm{~cm}$ ), and geoid model differences (as much as $30 \mathrm{~cm}$ ) (National Imagery and Mapping Agency, 2000; Roman and others, 2004). Considering error propagation of these individual uncertainties, absolute accuracy of elevation varies between a few centimeters to several meters. Data users are advised to exercise caution if computing channel slope between cross sections; the process incorporates these vertical accuracy considerations, as well as channel length, both of which are subject to relatively rapid spatial and temporal change in many study basins. 
Table 1. Monument geographic location source and quality summary statistics at the time of publication for this Mount St. Helens, Washington, database.

[Horizontal precision is unknown for 104 monuments (31 percent of total). Vertical precision is unknown for recreation-grade receivers-214 monuments (64 percent of total). m, meter; \%, percent; N/A, not applicable]

\begin{tabular}{|c|c|c|c|}
\hline Source Type & $\begin{array}{c}\text { Number of } \\
\text { monuments } \\
\text { surveyed } \\
\text { (percent of total) }\end{array}$ & $\begin{array}{l}\text { Average } \\
\text { horizontal } \\
\text { precision } \\
\text { (m) }\end{array}$ & $\begin{array}{l}\text { Average } \\
\text { vertical } \\
\text { precision }{ }^{1} \\
\text { (m) }\end{array}$ \\
\hline Map grade & $59(18 \%)$ & 0.17 & 0.23 \\
\hline Recreation grade & $214(64 \%)$ & 7.00 & N/A \\
\hline
\end{tabular}

${ }^{1}$ Precision values for recreation-grade receivers are computed using manufacturer algorithms (unpublished).

\section{Survey-Line Location}

Uncertainty associated with survey-line location has important implications to time-series analysis. In very rough terrain, line location errors of a few decimeters can be significant. In contrast, error exceeding several hundred meters might be acceptable, where channel geometry is uniform. Location accuracy is related to sourcedata type and defined in three classes - rectified, interpreted, and unrectified. The most accurate of these, rectified lines, are defined by monument locations (nodes). Average absolute accuracy of rectified survey line nodes is less than $3 \mathrm{~m}$. Error associated with interpreted survey lines is difficult to quantify because of the variety of ancillary data and methods used to estimate the location of one of the nodes. It is reasonable to consider interpreted survey-line location to be more certain than unrectified polylines, but less certain than rectified.

Unlike rectified and interpreted survey-line classes, defined by at least one monument location, unrectified lines are defined by digitized lines from 1:24,000-scale paper maps. Scans of these maps were georeferenced to the Lambert Conformal Conic projection and North American Datum of 1927 (NAD27) using bilinear interpolation and a first-order polynomial (affine) transformation . Survey lines were then digitized from these scans, attributed, and reprojected into UTM Z10N coordinates of NAD83. Some digitized polylines received further adjustments using coordinate geometry (COGO) operations from ancillary information such as bearing or maximum survey line length. The absolute accuracy of unrectified survey lines was evaluated by comparing digitized polylines to rectified survey lines determined from GNSS solutions. Georeferencing results, digitizing technique, and resulting node location and line length were used in the evaluation. RMSE of the georeferenced maps ranges from 1.1 to $10.0 \mathrm{~m}$ with a mean of $6.7 \mathrm{~m}$ and a 2-sigma standard deviation of $4.8 \mathrm{~m}$. Digitizing error was assumed to be zero due to the high-resolution scan and scale at which lines were digitized. For example, at a scale of 1:1,000, source-line width was often represented by eight or more pixels. A comparison of survey-line length and distance between nodes for unrectified survey lines that became rectified following GNSS observations on monuments is summarized in tables 2 and 3 .
Table 2. Selection of 46 unrectified survey lines before and after rectification, comparing line length in meters, for this Mount St. Helens, Washington, database.

[m, meter; RMSE, root-mean-squared-error]

\begin{tabular}{lcccc}
\hline \multicolumn{1}{c}{ Type } & $\begin{array}{c}\text { Average } \\
(\mathbf{m})\end{array}$ & $\begin{array}{c}\text { Standard } \\
\text { Deviation }(\mathbf{m})\end{array}$ & $\begin{array}{c}\text { Minimum } \\
(\mathbf{m})\end{array}$ & $\begin{array}{c}\text { Maximum } \\
(\mathbf{m})\end{array}$ \\
\hline Rectified & 484.7 & 354.2 & 66.4 & $1,372.4$ \\
Digitized & 687.3 & 522.4 & 119.5 & $1,998.5$ \\
Difference & 202.6 & 168.2 & 53.1 & 626.1 \\
\hline
\end{tabular}

Note: RMSE with 95-percent confidence interval is $417.6 \pm 210.7 \mathrm{~m}$.

Table 3. Selection of 90 unrectified survey lines before and after rectification, comparing distance between polyline nodes (that is, end point locations) in meters, for this Mount St. Helens, Washington, database.

[m, meter; RMSE, root-mean-squared-error]

\begin{tabular}{cccc}
\hline Average (m) & $\begin{array}{c}\text { Standard } \\
\text { Deviation (m) }\end{array}$ & Minimum (m) & Maximum (m) \\
\hline 176.8 & 158.7 & 8.3 & 646.7 \\
\hline
\end{tabular}

Note: RMSE with 95-percent confidence interval is $237.0 \pm 90.7 \mathrm{~m}$.

\section{Summary}

Three decades of stream-channel cross-section surveys at Mount St. Helens are compiled into a digital database. This database presents an exceptional record of the hydrogeomorphic response of rivers surrounding the volcano to the 1980 eruption. Geospatial data compilation, database design, and accuracy are summarized in this paper. The dynamic nature of the database will accommodate the addition of future surveys and data revisions as appropriate. 


\section{Acknowledgments}

A large number of people have been involved in the field effort, data reduction, database technical support, and review. Special consideration goes to Richard Janda for initial project establishment and Dave Meyer and Holly Martinson, who managed the cross-section project for the first decade following the 1980 eruption of Mount St. Helens. A large number of USGS Cascade Volcano Observatory (CVO) colleagues, past and present, were instrumental in collecting the actual survey data, and we are thankful for their efforts.

\section{References Cited}

Bangen, S.G., Wheaton, J.M., Bouwes, N., Jordan, C., Volk, C., and Ward, M.B., 2014, Crew variability in topographic surveys for monitoring instream fish habitat—A case study from the Columbia River Basin: Earth Surface Processes and Landforms, v. 39, p. 2070-2086.

Biedenharn Group, LLC, 2010, Toutle/Cowlitz River sediment budget: Biedenharn Group report for U.S. Army Corps of Engineers, Portland District, Mount St. Helens Project, $160 \mathrm{p}$.

Hardison, J.H., III, 2000, Post-lahar channel adjustment, Muddy River, Mount St. Helens, Washington: Fort Collins, Colorado State University, M.S. thesis, 119 p.

Janda, R.J., Meyer, D.F., and Childers, D., 1984, Sedimentation and geomorphic changes during and following the 1980-1983 eruptions of Mount St. Helens, Washington: Shin Sabo, v. 37, no. 2-3, p. 10-21 and p. 5-19.

Lipman, P.W., and Mullineaux, D.R., eds., 1981, The 1980 eruptions of Mount St. Helens, Washington: U.S. Geological Survey Professional Paper 1250, 844 p., http://pubs.er.usgs.gov/publication/pp1250.

Lisle, T.E., 1995, Effects of coarse woody debris and its removal on a channel affected by the 1980 eruption of Mount St. Helens, Washington: Water Resources Research, v. 31, no. 7, p. 1797-1808.

Major, J.J., 2004, Posteruption suspended sediment transport at Mount St. Helens-Decadal-scale relationships with landscape adjustment and river discharges: Journal of Geophysical Research, v. 109, p. 1-22.

Major, J.J., and Mark, L.E., 2006, Peak flow responses to landscape disturbances caused by the cataclysmic 1980 eruption of Mount St. Helens, Washington: Bulletin of the Geological Society of America, v. 118, p. 938-958.
Major, J.J., Mosbrucker, A.R., and Spicer, K.R., in press, Sediment erosion and delivery from Toutle River basin after the 1980 eruption of Mount St. Helens-A 30-year perspective, in Dale, V.H., and Crisafulli, C.M., eds., Ecological responses of Mount St. Helens-Revisited 35 years after the 1980 eruption: New York, Springer-Verlag.

Major, J.J., Pierson, T.C., Dinehart, R.L., and Costa, J.E., 2000, Sediment yield following severe volcanic disturbance-A two decade perspective from Mount St. Helens: Geology, v. 28, p. 819-822.

Meadows, T., 2014, Forecasting long-term sediment yield from the upper North Fork Toutle River, Mount St. Helens, USA: Nottingham, University of Nottingham, Ph.D. thesis, $358 \mathrm{p}$.

Meyer, D.F., and Dodge, J.E., 1988, Post-eruption changes in channel geometry of streams in the Toutle River drainage basin, 1983-1985, Mount St. Helens, Washington: U.S. Geological Survey Open-File Report 87-549, 226 p., http://pubs.er.usgs.gov/publication/ofr87549.

Meyer, D.F., and Martinson, H.A., 1989, Rates and processes of channel development and recovery following the 1980 eruption of Mount St. Helens, Washington: Hydrological Sciences Journal, v. 34, p. 115-127.

Meyer, D.F., Nolan, M.K, and Dodge, J.E., 1986, Posteruption changes in channel geometry of streams in the Toutle River drainage basin, 1980-82, Mount St. Helens, Washington: U.S. Geological Survey Open-File Report 85-412, 128 p., http://pubs.er.usgs.gov/publication/ ofr85412.

Martinson, H.A., Finneran, S.D., and Topinka, L.J., 1984, Changes in channel geometry of six eruption-affected tributaries of the Lewis River, 1980-82, Mount St. Helens, Washington: U.S. Geological Survey Open-File Report 84-614, 113 p., http://pubs.er.usgs.gov/publication/ ofr84614.

Martinson, H.A., Hammond, H.E., Mast, W.W., and Mango, P.D., 1986, Channel geometry and hydrologic data for six eruption-affected tributaries of the Lewis River, Mount St. Helens, Washington, water years 1983-84: U.S. Geological Survey Open-File Report 85-631, 161 p., http://pubs. er.usgs.gov/publication/ofr85631.

Mosbrucker, A.R., 2014, High-resolution digital elevation model of Mount St. Helens crater and upper North Fork Toutle basin, Washington, based on an airborne lidar survey of September 2009: U.S. Geological Survey Data Series 904, http://dx.doi.org/10.3133/ds904.

National Geodetic Survey, 2011a, GEOID03: National Geodetic Survey Web site accessed May 14, 2015, at http://www.ngs.noaa.gov/GEOID/GEOID03/. 
National Geodetic Survey, 2011b, GEOID09: National Geodetic Survey Web site accessed May 14, 2015, at http:/www.ngs.noaa.gov/GEOID/GEOID09/.

National Geodetic Survey, 2012, GEOID12A: National Geodetic Survey Web site accessed May 14, 2015, at http://www.ngs.noaa.gov/GEOID/GEOID12A/.

National Imagery and Mapping Agency, 2000, Department of Defense World Geodetic System 1984, its definition and relationships with local geodetic systems-National Imagery and Mapping Agency Technical Report TR8350.2, 3rd ed., amend. 1: National Geospatial-Intelligence Agency Web site accessed May 2012, at http://earth-info.nga.mil/ GandG/publications/tr8350.2/tr8350_2.html, 175 p.

Pierson, T.C., 1985, Initiation and flow behavior of the 1980 Pine Creek and Muddy River lahars, Mount St. Helens, Washington: Geological Society of America Bulletin, v. 96, p. 1056-1069.

Pierson, T.C., and Major, J.J., 2014, Hydrogeomorphic effects of explosive eruptions on drainage basins: Annual Review of Earth and Planetary Sciences, v. 42, p. 469-507.

Rydlund, P.H., Jr., and Densmore, B.K., 2012, Methods of practice and guidelines for using survey-grade global navigation satellite systems (GNSS) to establish vertical datum in the United States Geological Survey: U.S. Geological Survey Techniques and Methods, book 11, chap. D1, 102 p. with appendixes, http://pubs.usgs.gov/tm/11d1/.
Roman, D.R., Wang, Y.M., Henning, W., and Hamilton, J., 2004, Assessment of the new national geoid height model, GEOID03Proceedings of the American Congress on Surveying and Mapping 2004 meeting: National Geodetic Survey Web site accessed May 23, 2012, at http:/www.ngs.noaa.gov/GEOID/ geolib.html

Simon, A., 1999, Channel and drainage-basin response of the Toutle River system in the aftermath of the 1980 eruption of Mount St. Helens, Washington: U.S. Geological Survey Open-File Report 96-633, 130 p., http://pubs.er.usgs.gov/publication/ofr96633.

Simon, A., and Klimetz, D., 2012, Analysis of long-term sediment loadings from the upper North Fork Toutle River system, Mount St. Helens, Washington: Agricultural Research Service, National Sediment Laboratory, Technical Report Number 77, 103 p.

Swanson, F.J., and Major, J.J., 2005, Physical events, environments, and geological-ecological interactions at Mount St. HelensMarch 1980 to 2004, in Dale, V.H., Swanson, F.J., and Crisafulli, C.M., eds., Ecological responses to the 1980 eruption of Mount St. Helens: New York, Springer-Verlag, p. 27-44.

West Consultants, 2002, Mount St. Helens engineering reanalysis hydrologic, hydraulic, and sedimentation analysis: West Consultants report for U.S. Army Corps of Engineers, Portland District, Mount St. Helens Project, 177 p.

Zheng, S., Wu, B., Thorne, C., and Simon, A, 2014, Morphological evolution of the North Fork Toutle River following the eruption of Mount St. Helens, Washington: Geomorphology, v. 208, p. 102-116. 

Produced in the Menlo Park Publishing Service Center, California Manuscript approved on August 2, 2015

Edited by James W. Hendley II

Layout by Cory D. Hurd 


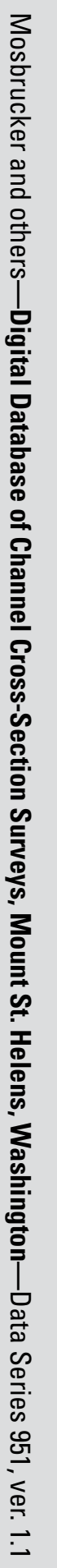

